position and functions of the local organizations of the Woman's Committee are similar, in their application to women, to those of the state councils of defense. In most states, the state divisions of the Woman's Committee and the state councils of defense are effectively drawn together, through the fact that the state and county units of the Woman's Committee operate as the Woman's Committee of the respective state and county councils of defense. Thus the Council of National Defense, through its state and local councils of defense and state and local units of its Woman's Committee, has established an organization reaching with the message of the war the individual citizens of this nation and enlisting and directing their efforts in effective and necessary war work.

The following articles, concerning the work of these bodies and their local agencies in its relation to war relief, are written by persons closely in touch with the work of the Woman's Committee of the Council of National Defense and of the State Councils Section. These articles, descriptive of a part of the work accomplished by these agencies in the states, are not, however, in any way, official statements of the Council of National Defense.

\title{
DEPARTMENT. OF HOME AND FOREIGN RELIEF OF THE WOMAN'S COMMITTEE
}

\author{
By Elisabeth Carey, \\ Information Department, Woman's Committee.
}

The Woman's Committee was organized at a time when the attention of the country was turning with renewed intensity to the alleviation of the sufferings caused by the war. Women everywhere were flocking in steadily increasing numbers to the surgical dressings room. Every day saw new efforts to supply the wants of war refugees. Knitting was fast becoming the occupation of every spare moment. It was obvious, then, that any organization which had for its avowed purpose the encouragement and coördination of women's endeavor, must include in its program some provision for relief work. Accordingly, the Department of Home and Foreign Relief was created.

In realizing the powerful appeal of such work and the oppor- 
tunities which it offers for the tangible expression of a will to serve, the Woman's Committee by no means overlooked the fact that the American Red Cross, because of its authoritative position, its recognized efficiency and its transportation facilities, had become a center for all relief activities, and that most women had already affiliated themselves with that organization. It was decided, therefore, that the function of the Department of Home and Foreign Relief should be coöperative rather than initiative; and steps were immediately taken to put the Woman's Committee on terms of mutual helpfulness with the Red Cross.

The service rendered has consisted for the most part in putting the state and local machinery of the Woman's Committee at the command of the Red Cross and other relief societies. Since the machinery involves an organization which extends in some cases not only to counties and townships but to school districts, city wards and even blocks, embracing altogether an aggregate of approximately 14,000 units with a leader in each, it has been of no mean assistance in recruiting members, raising money, and giving publicity to such projects as the adoption of French orphans and the rehabilitation of French villages. In intensive drives for funds or members these workers of the Woman's Committee have been especially useful. The Red Cross found in Topeka, Kansas, a chairman in each ward and a captain with from five to twenty lieutenants in each precinct ready to canvass the entire town in a single day. In Tampa, Florida, during the Christmas campaign for members, the Woman's Committee added 7,000 names to the Red Cross roster. These instances have been paralleled in many localities. Nor has the Red Cross been the only agency to seize this opportunity of securing an organized band of aides eager for service. During the drive conducted by the Young Women's Christian Association to finance their War Work Council the representatives of the Woman's Committee in the state of Washington collected the assigned quota of $\$ 100,000$.

The members of local committees have often been able to bring into touch with relief societies women who otherwise might never have been reached. In one state where roads are rough and railways are few, the coming of the Woman's Committee has in several counties meant the beginning of Red Cross work. In Michigan, local units of the Woman's Committee undertook to secure a 
supplementary force of knitters among those whose services; by some untoward circumstance, the Red Cross had not yet been able to enlist. The result was an overwhelming response from school children, firemen, aged grandmothers, women in institutions, - all eager to do something for their country but up to this time lacking the opportunity. In another state the translation of knitting instructions into Danish brought to the Red Cross a number of very efficient workers. To the Home Service Section of the American Red Cross, the Department of Home and Foreign Relief has, through its local workers, been able to render some assistance by spreading information as to allotments and War Risk Insurance or by calling attention to soldiers' families in need of advice or aid.

Although the general policy of the Department of Home and Foreign Relief has been to further the activities of existing agencies for relief rather than to carry on independent work through the units of the Woman's Committee, in some emergencies it has been possible for this Department to supplement the work done by other organizations. For instance, last fall when an early snow storm came upon a cantonment in the Ohio valley, the women of the vicinity immediately collected a fund and through a mail order house supplied the soldiers with much needed woolen clothing. In the same way, other units of the Woman's Committee have been able to raise funds and supply unmistakable local needs without fear of encroaching upon the work of other organizations or of lessening in any way their ability in the larger service of coöperation. 